\title{
Pancreatitis in adult with acute lymphoblastic leukemia using L-asparaginase and simvastatin: case report and systematic review
}

\author{
Pancreatite em adulto com leucemia linfoblástica aguda usando L-asparaginase e \\ sinvastatina: relato de caso e revisão sistemática
}

Renne Rodrigues $^{1 *}$, Diogo D. Gavarrete ${ }^{2}$, Érika A. T. Bernardi ${ }^{3}$, Eduardo C. Munhoz ${ }^{4}$.

\begin{abstract}
Context: Acute pancreatitis is a inflammatory process of the pancreas. It can be caused by gallstones, metabolic disorders, associated or not with alcohol abuse, or medication. Case Report: A 38-year-old man was admitted to the hospital because of worsening of nausea, abdominal pain, dizziness and white stool. Patient was diagnosed with severe acute pancreatitis. After six days of hospitalization, patient progressed into hypotension and severe bradycardia, and died. The patient used simvastatin chronically, and was in treat with L-asparaginase, both drugs related to the occurence of acute pancreatitis separately. Naranjo's probability scale of adverse drug reaction established the causality between these medications and acute pancreatitis as probable. However, due to the absence of reports of causality, the acute pancreatitis is associated with to the use of L-asparaginase with possible drug interactions with simvastatin. Conclusion: It is very important to monitor patients treated with L-asparaginase, through careful observation of clinical signs and laboratory follow-up, as well as verification of other medications in use. The AP may have different levels of severity, being indispensable the quick diagnosis and early treatment.
\end{abstract}

Key Words: Precursor Cell Lymphoblastic Leukemia-Lymphoma. Asparaginase. Pancreatitis. Simvastatin. Drug Interaction.

\section{RESUMO}

Contexto: Pancreatite aguda é um processo inflamatório do pâncreas. É causada por cálculos biliares, desordens metabólicas, associadas ou não ao uso abusivo de álcool, ou medicamentos. Relato do Caso: Homem de 38 anos foi admitido no hospital em razão do agravamento de náuseas, dor abdominal, tontura e fezes brancas. O paciente foi diagnosticado com pancreatite aguda. Após seis dias de

1. Resident in Hospital Pharmacy and Clinical Pharmacy, Hospital Erasto Gaertner, Curitiba/PR,Brazil. Masters in Public Health, University Londrina State; Professor at University of Northern Paraná. Londrina/PR, Brazil.

2. MD. Resident in Clinical Oncology, Hospital Erasto Gaertner, Curitiba/PR, Brazil.

3. Resident in Hospital Pharmacy and Clinical Pharmacy, Hospital Erasto Gaertner, Curitiba/PR, Brazil. Pharmaceutical Hospital São Joaquim Portuguese Beneficent, São Paulo/SP, Brazil.

4. MD. Department of Clinical Oncology, Hospital Erasto Gaertner, Curitiba/PR, Brazil.

Work developed in Hospital Erasto Gaertner, Curitiba, PR, Brazil.
Correspondencia

Renne Rodrigues

Hospital Erasto Gaertner, Curitiba, Brazil.

Recebido em 08/07/2014

Aprovado em 29/05/2015 
internação, paciente progrediu com hipotensão e bradicardia severa, evoluindo à óbito. O paciente fazia uso crônico de sinvastatina, e estava em tratamento com L-asparaginase, ambos fármacos, de modo separado, são relacionados com a ocorrência de pancreatite aguda severa. O algoritmo de Naranjo para estabelecimento de reação adversa a medicação classificou a causalidade entre as medicações citadas e a pancreatite aguda como provável. Porém, em razão da ausência relatos dessa causalidade, associa-se a pancreatite aguda ao uso de L-asparaginase, com possível interação medicamentosa com sinvastatina. Conclusão: É de suma importância o acompanhamento clínico e laboratorial de pacientes em uso de Lasparaginase para sinais de pancreatite aguda, sendo imprescindível o rápido diagnóstico e tratamento precoce.

Palavras-chave: Leucemia-Linfoma Linfoblástico de Células Precursoras. Asparaginase. Pancreatite. Sinvastatina. Toxicidade de Drogas.

\section{Introduction}

Acute pancreatitis is an inflammatory process of the pancreas, usually reversible. It can be caused by gallstones, metabolic disorders, associated or not with alcohol abuse, or medication. ${ }^{1,2}$ The clinical diagnosis of acute pancreatitis is based on characteristic abdominal pain and nausea, combined with elevated serum levels of pancreatic enzymes (amylase and lipase) and abdominal imaging by computed tomography (CT), magnetic resonance imaging, or transabdominal ultrasonography. ${ }^{2}$

L-asparaginase is a strategic medicine for the cure of acute lymphoblastic leukemia (ALL) in adults, increasing overall survival. ${ }^{3}$ However, this benefit brings with it potential side effects such as anaphylaxis and problems in the liver and pancreas. ${ }^{4}$ The pancreatitis may develop into pancreatic pseudocyst, panniculitis, among other complications such as infections. There is also the risk of developing chronic sequelae, such as prolonged pancreatic exocrine insufficiency. ${ }^{1,5-8}$

\section{Case report}

A 38-year-old man, caucasian, with dyslipidemia, treated with simvastatin $20 \mathrm{mg}$ once a day for more than one year, with no history of alcoholism. He was diagnosed with B-cell ALL, was treated with the protocol CALGB 88116, which includes Lasparaginase Escherichia coli-derived drug twice a week, six applications in the induction course, and four times during early intensification. Patient completed the induction featuring complete remission, with $1.2 \%$ of immature cells in bone marrow, began the early intensification phase one month after induction. Early intensification also occurs in association with cyclophosphamide, cytarabine, dexamethasone, vincristine and intrathecal methotrexate.

On the $25^{\text {th }}$ day of the early intensification, three days after the $11^{\text {th }}$ dose of L-asparaginase, the patient developed nausea and malaise, thus did not return to hospital and did not get the last application of L-asparaginase. On the $28^{\text {th }}$ day, six days after the $11^{\text {th }}$ dose of L-asparaginase, he returns to the hospital, reporting worsening of nausea, abdominal pain, dizziness and white stool. Exams performed in the emergency lab showed abnormal levels of amylase, lipase, lactate dehydrogenase (LDH), Creactive protein (CRP) and total bilirubin (Table 1 ), and the patient was admitted with suspected pancreatitis. When the patient was hospitalized more tests were performed, gamma glutamyl transferase and prothrombin time presents normal results.

A CT scan showed pancreas increased volume without significant necrosis or evidence of gallstones. Differential diagnosis confirmed the hypothesis of Acute Pancreatitis (AP), discarding hypertriglyceridemia, alcohol and gallstones as causative agents. This cause was associated with medications, specifically L-asparaginase with possible participation of simvastatin. The Naranjo probability scale ${ }^{9}$ was applied in order to establish the causality of the adverse drug reaction occurrence. According to this scale, the probability of asparaginase and simvastatin being the cause of pancreatitis was classified as probable, reaching 5 points.

To establish the risk of severe disease the Ranson's Score was performed, with basis in whitecell count, age and levels of LDH and alanine aminotransferase ${ }^{10}$. Score 5 was obtained, indicating risk of death of $40 \%$. Score APACHE II was carried 
Table 1. Exams performed in hospitalization period, six days after the 11th dose of L-asparaginase.

\begin{tabular}{|c|c|c|c|}
\hline \multirow[b]{2}{*}{ Exams (RR) } & \multicolumn{3}{|c|}{ Days of hospitalization } \\
\hline & $1^{\text {st }}$ & $2^{\text {nd }}$ & $5^{\text {th }}$ \\
\hline Amylase (30-110U/L) & 498 & 119 & 101 \\
\hline Lipase (23-300U/L & 6.307 & 1.582 & 1.196 \\
\hline LDH (313-618U/L & 2.221 & 1813 & 1.239 \\
\hline CRP $(0-1 \mathrm{mg} / \mathrm{dL}$ & 18,1 & 21,6 & 45,5 \\
\hline Total bilirubin $(0,20-1,30 \mathrm{mg} / \mathrm{dL})$ & 1,99 & 3,47 & 2,70 \\
\hline Platelets $\left(150.000-400.000 \mathrm{~mm}^{3}\right)$ & 402.000 & 10.000 & 95.000 \\
\hline White-cell count $\left(4.000-11.000 \mathrm{~mm}^{3}\right)$ & 9.320 & 3.300 & 5.200 \\
\hline Hematocrit $(42,5-52,9 \%)$, & 49,5 & 30,2 & 33,1 \\
\hline Hemoglobin $(14,3-18,3 \mathrm{~g} / \mathrm{dL})$ & 16,5 & 9,2 & 9,7 \\
\hline Phosphorus $(2,5-4,5 \mathrm{mg} / \mathrm{dL})$ & - & 11,6 & - \\
\hline Magnesium $(1,6-2,3 \mathrm{mg} / \mathrm{dL})$ & - & 3,7 & - \\
\hline Potassium $(3,5-5,1 \mathrm{mEq} / \mathrm{L})$ & - & 5,9 & - \\
\hline Calcium $(8,4-10,2 \mathrm{mg} / \mathrm{dL})$ & - & 5,4 & - \\
\hline Glucose $(74-106 \mathrm{mg} / \mathrm{dL})$ & - & 38 & 35 \\
\hline Triglycerides* & - & 317 & - \\
\hline
\end{tabular}

RR: Reference range. LDH: Lactate dehydrogenase. CRP: C-reactive protein. ${ }^{*} \mathrm{RR}$ of triglycerides: normal $<150 \mathrm{mg} / \mathrm{dL}$, high limit $151-199 \mathrm{mg} / \mathrm{dL}$, high $200-499 \mathrm{mg} / \mathrm{dL}$.

out, showing 18 points, equivalent to a $25 \%$ risk of death, therefore, considered as severe AP.

The patient was kept in absolute fasting, being hydrated and corrected hypokalemia (still presenting thombocitopenia and leukopenia). Improvement in the second day of hospitalization was subjective, and started on the $4^{\text {th }}$ day enteral nutrition.

On 5th day of hospitalization, there was an improvement of amylase and LDH, but there was a rise of CRP (Table 1), associated with clinical suspicion of infection. For this reason antibiotic treatment (meropenem) was started. Throughout the day the patient developed worsening of respiratory pattern, stable tachycardia, repetitive cases of hypoglycemia and confusion, supporting suspicion of sepse for AP infected. Patient was immediately transferred to Intensive Care Unit.

Overnight, patient had hypotension and metabolic acidosis, was intubated and medicated for aci- dosis and also treated with vasoactive drugs. In the morning of 6th day of hospitalization, patient progressed into hypotension, severe bradycardia, and died.

\section{Discussion}

The most common causes for AP are alcoholism and presence of gallstone ${ }^{2,10}$, but these hypotheses were discarded after the differential investigation. The real role of hypertriglyceridemia as cause of AP is unknown, but the patient levels in the hospitalized period, although high, don't support this theory. The AP was attributed to medications in use, specifically L-asparaginase, with possible participation of simvastatin.

A systematic search was conducted in the main electronic databases (PubMed, Cochrane Library, Lilacs, and SciELO), in order to find work to 
report the occurrence of pancreatitis in association with the use of asparaginase and/or simvastatin in humans. For research no limits were applied regarding the date of publication, the language used or the type of article (Table 2 ).

L-asparaginase is one of the drugs with association with AP. The first reports of L-asparaginaseassociated pancreatitis (AAP) started in the decade of $60^{\prime} \mathrm{s}^{11}$. However, this is not a very common reaction, which varies from 2 to $19 \%^{1,12-14}$, and fatal, with mortality rates ranging from zero to $5 \%$ of cases of pancreatitis ${ }^{4,14,15}$. There is no relationship of dose or duration in treatment for pancreatitis, it usually appears after the fourth or sixth application. However there are reports of AAP on the first application $^{1,2,12,16,17}$. Symptoms begin about 4 days after application, but may vary from 1 to 13 days ${ }^{1,12,16}$.

Most cases of AAP occur in pediatric patients, since it is recommended for the treatment of acute lymphocytic leukemia. This disease affects mainly children. Patients from 10 to 18 years old have an increased risk of 2.4 times to develop AAP, comparing with patients with less than 10 years old ${ }^{1}$. There are no studies comparing the risk among children and adults.

Simvastatin alone is also correlated with pancreatitis, however without reported deaths ${ }^{18-21}$. In some cases it was combined with fenofibrate ${ }^{22}$ and salicylate ${ }^{23}$, both followed by death.

The use of a drug usually generates various compounds, which in certain cases may interact unpredictably with tissues, leading toxicity. To better assess whether the use of a drug is causal or casual, this relationship is classified into certain, probable, possible, unlikely, conditional or unclassifiable ${ }^{24}$. Naranjo's probability scale of adverse drug reaction established the causality between these medications and AP as probable ${ }^{9}$. Several evaluation criteria of the Naranjo's scale could not be evaluated because of non reexposure and

Table 2. Systematic review of the literature performed on March 29, 2014.

\begin{tabular}{|c|c|c|c|}
\hline Electronic databases & Search Strategy & Found & Results \\
\hline \multirow[t]{7}{*}{ PubMed $\neq$} & Asparaginase* AND Pancreatitis* & 87 & 17 Original articles \\
\hline & & & 12 Reviews \\
\hline & & & 43 Case reports \\
\hline & & & 4 Letters \\
\hline & Simvastatin* AND Pancreatitis* & 12 & 8 Case reports \\
\hline & & & 1 Letter \\
\hline & Asparaginase* AND Simvastatin* AND Pancreatitis* & - & - \\
\hline \multirow[t]{3}{*}{ Cochrane Library $\ddagger$} & Asparaginase AND Pancreatitis & 10 & 3 Original articles; \\
\hline & & & 2 Case reports \\
\hline & Simvastatin AND Pancreatitis & 6 & - \\
\hline \multirow[t]{3}{*}{ Lilacs } & Asparaginase§ AND Pancreatite§ & 3 & 3 Case reports \\
\hline & Simvastatina§ AND Pancreatite§ & - & - \\
\hline & Asparaginase§ AND Sinvastatina§ AND Pancreatite§ & - & - \\
\hline \multirow[t]{3}{*}{ Scielo } & Asparaginase AND Pancreatite & 1 & 1 Case report \\
\hline & Simvastatina AND Pancreatite & 1 & 1 Review \\
\hline & Asparaginase AND Sinvastatina AND Pancreatite & - & - \\
\hline
\end{tabular}

‡Search in title and abstract; * Medical Subject Headings; §Descritores em Ciências da Saúde. 
severity of the case, a fact that may have hindered a better definition of causality. In addition, cases of AAP described in the literature do not follow the evolution of classical immediate onset of symptoms and dose-response relationship.

Although there are several reports of pancreatitis associated with L-asparaginase and few associated with simvastatin did not find any reports of a possible pancreatitis caused by both these drugs, including or others references source 25,26 . For this reason, the AP is associated to L-Asparaginase, with possibility of a synergistic effect between simvastatin and L-Asparaginase, reinforces the importance of pharmacovigilance of these drugs.

\section{Conclusion}

This case shows the importance of monitoring patients treated with L-asparaginase, through careful observation of clinical signs and laboratory follow-up, as well as verification of other medications in use. The AP may have different levels of severity, being indispensable the quick diagnosis and early treatment.

\section{References}

1. Kearney SL, Dahlberg SE, Levy DE, Voss SD, Sallan SE, Silverman LB. Clinical course and outcome in children with acute lymphoblastic leukemia and asparaginase-associated pancreatitis. Pediatr Blood Cancer. 2009;53:162-7.

2. Carroll JK, Herrick B, Gipson T, Lee SP. Acute pancreatitis: diagnosis, prognosis, and treatment. Am Fam Physician. 2007;75:1513-20.

3. Wetzler M, Sanford BL, Kurtzberg J, DeOliveira D, Frankel SR, Powell BL, et al. Effective asparagine depletion with pegylated asparaginase results in improved outcomes in adult acute lymphoblastic leukemia: Cancer and Leukemia Group B Study 9511. Blood. 2007; 109:4164-7.

4. Haskell C, Canellos G, Leventhal B, Carbone P, Block J, Serpick $A$, et al. L-asparaginase: therapeutic and toxic effects in patients with neoplastic disease. [abstract]. N Engl J Med.1969;281:1028-34.

5. Chiewchengchol D, Wananukul S, Noppakun N. Pancreatic panniculitis caused by L-asparaginase induced acute pancreatitis in a child with acute lymphoblastic leukemia. Pediatr Dermatol. 2009;26:47-9.

6. Larson RA, Dodge R, Burns C, Lee E, Stone R, Schulman P, et al. A five-drug remission induction regimen with intensive consolidation for adults with acute lymphoblastic leukemia: cancer and leukemia group B study 8811. Blood. 1995;85:202537.

7. Yu C, Lin K, Lin D, Chen R, Horng Y, Chang M. L-asparaginase-related pancreatic pseudocyst: report of a case. J Formos Med Assoc. 1994; 93:441.
8. Yasui I, Shimokawa T, Kasai M, Yamada H, Watanabe E, Takeyama $\mathrm{H}$, et al. A case of ALL complicated with acute pancreatitis and pancreatic pseudocyst caused by L-asparaginase. [abstract]. Gan To Kagaku Ryoho.1993;20:149-52.

9. Naranjo CA, Busto U, Sellers EM, Sandor P, Ruiz I, Roberts $\mathrm{E}$, et al. A method for estimating the probability of adverse drug reactions. Clin Pharmacol Ther. 1981;30:239-45.

10. Whitcomb DC. Clinical practice. Acute pancreatitis. N Engl J Med. 2006;354:2142-50

11. Haskell CM, Canellos GP, Leventhal BG, Carbone PP, Block JB, Serpick AA, et al. L-asparaginase: therapeutic and toxic effects in patients with neoplastic disease. [abstract]. N Engl J Med.1969;281:1028-34.

12. Morimoto $A$, Imamura $T$, Ishii $R$, Nakabayashi $Y$, Nakatani $T$, Sakagami J, et al. Successful management of severe L-asparaginase-associated pancreatitis by continuous regional arterial infusion of protease inhibitor and antibiotic. Cancer. 2008;113:1362-9.

13. Knoderer HM, Robarge J, Flockhart DA. Predicting asparaginase-associated pancreatitis. Pediatr Blood Cancer. 2007;49:634-9.

14. Alvarez OA, Zimmerman G. Pegaspargase-induced pancreatitis. Med Pediatr Oncol. 2000;34:200-5.

15. Weetman RM, Baehner RL. Latent onset of clinical pancreatitis in children receiving L-asparaginase therapy. Cancer. 1974;34:780-5

16. Treepongkaruna S, Thongpak N, Pakakasama S, Pienvichit $\mathrm{P}$, Sirachainan N, Hongeng S. Acute pancreatitis in children with acute lymphoblastic leukemia after chemotherapy. J Pediatr Hematol Oncol. 2009;31:812-5.

17. Sahu S, Saika S, Pai SK, Advani SH. L-asparaginase (Leunase) induced pancreatitis in childhood acute lymphoblastic leukemia. Pediatr Hematol Oncol. 1998;15:533-8.

18. Nitsche CJ, Jamieson N, Lerch MM, Mayerle JV. Drug induced pancreatitis. Best Pract Res Clin Gastroenterol. 2010;24:14355.

19. Johnson JL, Loomis IB. A case of simvastatin-associated pancreatitis and review of statin-associated pancreatitis. Pharmacotherapy. 2006;26:414-22.

20. Murinell A, Pinheiro E. Acute pancreatitis due to simvastatin. GE, J Port Gastrenterol. 2006;13:92-6.

21. Singh S, Loke YK. Statins and pancreatitis: a systematic review of observational studies and spontaneous case reports. Drug Saf. 2006;29:1123-32.

22. McDonald KB, Garber BG, Perreault MM. Pancreatitis associated with simvastatin plus fenofibrate. Ann Pharmacother. 2002;36:275-9.

23. Antonopoulos S, Mikros S, Kokkoris S, Protopsaltis J, Filioti $\mathrm{K}$, Karamanolis D, et al. A case of acute pancreatitis possibly associated with combined salicylate and simvastatin treatment. JOP J Pancreas. 2005;6:264-8.

24. WHO. World Health Organization. Uppsala Monitoring Centre 2015 [2015 (Mayo 27)]. Available from: http://who-umc.org.

25. Micromedex®. Healthcare Series [Internet database] Greenwood Village, Colo: Thomson Healthcare; 2014 [Accessed in 2014 (Mar 29).]. Available from: http://wwwmicromedexsolutions-com.ez78.periodicos.capes.gov.br/ micromedex2/librarian.

26. Tatro DS. Drug interaction facts. St Louis: Wolters Kluwer Health; 2008. 